\title{
DOES THE INSTITUTIONAL ENVIRONMENT AFFECT CSR DISCLOSURE? THE ROLE OF GOVERNANCE
}

\author{
Há Influência do ambiente institucional nas práticas de divulgação de RSC? O \\ papel da governança \\ ¿El entorno institucional influye en las prácticas de revelación de información \\ de la RSC? El papel del Gobierno Corporativo
}

\begin{abstract}
The aim of this article is to analyze whether the institutional environment has a direct effect on Corporate Social Responsibility (CSR) reporting practices or if this effect is explained by the influence of the institutional environment on Corporate Governance (CG) mechanisms. To conduct our study, we focused on two countries that reflect different types of institutional environment: relation-based (Brazil) and rule-based (Spain). Based on our results, we can affirm that the institutional environment influences CG mechanisms (Board Size and Reference Shareholder) as well as companies' CSR disclosure. Additionally, the CG mechanisms affected by the institutional environment also help to explain differences in CSR reporting practices. As relation-based societies evolve into rules-based environments, the information disclosed about CSR becomes more complex due to a strengthening of CG mechanisms.
\end{abstract}

KEYWORDS | Corporate governance, disclosure, corporate social responsibility, institutional environment, ownership structure.

\section{RESUMO}

O objetivo desta investigação é examinar se o efeito do ambiente institucional sobre as práticas de divulgação de informações de Responsabilidade Social Corporativa (RSC) é direto ou se é devido à influência desse ambiente sobre as características de Governança Corporativa (GC). Neste sentido, são comparados dois ambientes institucionais: o Brasil, porque é centrado nas relações, e a Espanha, porque é centrada em normas. A partir dos resultados obtidos, pode-se deduzir que o ambiente institucional influencia características da GC (Tamanho do Conselho de Administração e Acionista de Referência), bem como a divulgação sobre a RSC. Além disso, essas características da GC são influenciadas pelo ambiente institucional e, por sua vez, explicam as diferenças encontradas nas práticas de divulgação de informações de RSC. Assim, à medida que as sociedades centradas nas relações evoluem para outras centradas em normas, as informações divulgadas sobre RSC tornam-se mais complexas, devido ao fortalecimento das características da GC.

PALAVRAS-CHAVE / Governança corporativa, divulgação de informações, responsabilidade social corporativa, cultura nacional, estrutura acionista.

\section{RESUMEN}

El objetivo es examinar si el efecto que el entorno institucional ejerce sobre la información divulgada sobre la Responsabilidad Social Corporativa (RSC) es directo o si se explica por la influencia que este entorno tiene sobre las características del Gobierno Corporativo. Para ello, se comparan dos entornos institucionales distintos: Brasil (Centrado en las Relaciones) y España (Centrado en las Normas). Considerando los resultados concluimos que el entorno ejerce una influencia sobre los mecanismos del Gobierno Corporativo (Tamaño del Consejo y Accionista de Referencia), y la divulgación de la Responsabilidad Social Corporativa. Además, estas características del Gobierno Corporativo, afectadas por el entorno, son las que a su vez explican estas diferencias encontradas en las prácticas de divulgación de información sobre la Responsabilidad Social Corporativa. En la medida en la que las sociedades Centradas en las Relaciones evolucionen hacia otras Centradas en las Normas, la información divulgada sobre la Responsabilidad Social Corporativa será más compleja debido al fortalecimiento de los mecanismos del Gobierno Corporativo.

PALABRAS CLAVE I Gobierno corporativo, divulgación de información, responsabilidad social corporativa, entorno institucional, estructura de propiedad. 


\section{INTRODUCTION}

Today, the importance of Corporate Social Responsibility (CSR) in business is undeniable (Lee, 2008) as well as the relevance of CSR communication strategy. Despite the diversity of options available to disclose about CSR (Ihlen, Bartlett, \& May, 2011), most companies have chosen to do it by means of a CSR/ sustainability report.

The publication of sustainability reports has increased significantly in recent years (KPMG, 2011) even though CSR disclosure is not mandatory in most countries. Studies have pointed a few reasons behind this growth in CSR disclosure, particularly the responsibility of companies towards their stakeholders in the pursuit of legitimacy (Crowther, 2000), the rewards companies expect for their socially/ environmentally friendly behaviors and for decreasing information asymmetries (Bushman, Piotroski, \& Smith, 2004), and the various pressures from their environment (Young \& Marais, 2012).

According to previous empirical evidence, the majority of these external pressures come from the industry (Sweeney \& Coughlan, 2008) and the institutional environment in which they operate (Adams, 2002; Chen \& Bouvain, 2009; Golob \& Bartlett, 2007; Kolk \& Perego, 2010; Michelon, Pilonato, \& Ricceri, 2015; Prado, Gallego, \& García, 2009), which clearly determines the degree of engagement in CSR disclosure practices.

It is theoretically consistent with Institutional Theory to affirm that organizations adapt their structures and policies to institutional norms (Dimaggio \& Powell, 1983) in order to survive in the market. However, research on the effects of the institutional environment can be complex due to the significant difficulty to isolate variables and distinguish those effects from the impact the institutional environment has on other internal-context variables (Adams, 2002).

In this perspective, we should consider that this institutionalization process also affects Corporate Governance (CG) mechanisms (Charkham, 1994; Doidge, Karolyi, \& Stulz, 2007; Klapper \& Love, 2004; Porta, Lopez-De-Silanes, \& Shleifer, 1999). These mechanisms are not limited to the Board of Directors (BD), comprehending also other features of the ownership structure of companies.

The considerations above and the evidence that sustainability disclosure policies emerge from BD (as supported by Agency and Stakeholder Theories - Freeman, 1984; Jensen \& Meckling, 1976) motivate us to inquire whether the institutional environment has a direct effect on CSR reporting practices or if this effect is partially explained by the influence that the institutional environment has on companies' CG characteristics.

Consequently, the aim of this article is to analyze whether the institutional environment has a direct effect on CSR reporting practices of if this effect is explained by the influence of the institutional environment on CG mechanisms.

According to suggestions by several researchers (Adams, 2002; Young \& Marais, 2012) and considering the aim of our study, we focused on a comparison between two countries: Brazil and Spain. This is because these country's institutional environments are clearly different (Li \& Filer, 2007) and because both countries have been considered pioneers or top-ranked in the reporting of CSR information (Gallego, Formigoni, \& Antunes, 2014; Grecco, Filho, Segura, García, \& Rodríguez, 2013; KPMG, 2013; Sierra, Zorio, \& García, 2013). Additionally, according to previous empirical evidence, there are differences concerning CG mechanisms: Brazilian companies' BDs are weaker and less effective than Spanish ones (Andrés, Azofra, \& Lopez, 2005; Black, Carvalho, \& Gorga, 2010).

Thus, our sample consists of 125 listed companies from Brazil and Spain with CG and financial data available at the ASSET4 Database (an international database with information about listed companies' CG and (SR).

In our study, we used measures that reflect the complexity of companies' CSR reporting. We used an index intended to reflect CSR reporting practices; we considered also the actions taken to increase the credibility and quality of such disclosures (Amran, Lee, \& Devi, 2014; Boiral, 2013); the extent to which the disclosed information followed the Global Reporting Initiatives (GRI) guidelines; whether such adequacy was subject to external checking; and, finally, whether the information had been assured. With regard to CG mechanisms, we focused on the ones indicated by the literature as having an influence on CSR reporting practices: Board Size, Board Independence, Board Activity, CSR Committee, and Reference Shareholder.

Considering our results, we can affirm that the institutional environment has a strong influence on the complexity of the CSR reporting practices as well as on two of the CG mechanisms analyzed: Board size and the presence of a Reference Shareholder. Moreover, these two CG characteristics are the ones that significantly affect CSR disclosure. When CG variables are introduced in the analysis, the institutional environment alone no longer has any significant effect on CSR reporting. Therefore, we can conclude that the effect of the institutional environment on CSR reporting practices is mediated by CG mechanisms, particularly Board Size and the existence of a Reference Shareholder.

With regard to the composition of our sample, it is worth highlighting that, in rule-based societies, the information disclosed about CSR presents a higher level of complexity than in relation-based societies.

The present article is organized as follows. In the next two sections, we focus on the theoretical framework adopted, a review of the literature, and the development of our hypotheses. In the following section, we look more closely into the sample and the 
variables chosen, as well as the methodologies employed. After that, we present the results of our study and a discussion about our subject. Finally, in the last section, we present our conclusions, the limitations of the study, and mention some of the lines of investigation that remain open.

\section{CSR DISCLOSURE}

Communicating CSR has become a priority for companies in order to ensure the satisfaction of stakeholders' demands. Although there is a wide range of alternatives for how to report about CSR (Ihlen et al., 2011), most companies choose to include CSR-related information in their official written documents since markets, investors and stakeholders usually recognize this way better than other options (Gray, Kouhy, \& Lavers, 1995).

Once a company has decided to report about CSR in its documents, the next step is to choose whether it is going to do that in its annual reports or through a more specific document, i.e., the sustainability or CSR report. This document aims to inform stakeholders about the social, environmental and economic impact (Triple Bottom Line approach - Elkington, 1998) of companies' activities during a given financial year (Rodríguez, Frías, \& García, 2014).

In recent years, there has been an increase in the information disclosed about CSR (KPMG, 2013). However, the credibility and quality of CSR reports have been challenged (Boiral, 2013; Amran et al., 2014). Consequently, companies have started to implement some more complex CSR disclosure practices in order to make their reports more credible.

Thus, companies can decide to report according to international standards (GRI guidelines) in order to enable the comparison and harmonization of CSR information between companies (Adams, 2002; Boiral, 2013). Later, these reports can get a specific "application level”, which reflects to what extent each company's report follows the GRI guidelines. Kolk and Perego (2010), García, Sierra, and Zorio (2013), and Castelo, Delgado, Ferreira, and Pereira (2014), among other scholars, argue that the adoption of the GRI guidelines is an important driver for enhancing the quality of CSR/sustainability reports. Moreover, this application level can be self-reported or externally checked (by a third-party or GRI). In this respect, the external checking of a CSR report's adequacy to GRI gives more credibility to the report (Fernández, Romero, \& Ruiz, 2012; Prado et al., 2009).

Finally, the maximum level of information complexity is provided by the assurance of the CSR report. This is generally perceived as a mechanism to secure CSR reports' credibility (Fernández, Romero, \& Ruiz, 2014; Simnett, Vanstraelen, \& Chua, 2009) and quality (García et al., 2013; Perego \& Kolk, 2012).

\section{CSR REPORTING, CORPORATE GOVERNANCE MECHANISMS AND INSTITUTIONAL ENVIRONMENT}

Several researchers have inquired about what factors could explain the differences found in CSR disclosure practices. Empirical evidence suggests that, in addition to industry pressures and the institutional environment, other factors that can significantly affect CSR reporting practices are company size, profitability and CG mechanisms.

Firstly, differences in the level of adoption of CSR disclosure practices have been detected between companies depending on their size (Clarkson, Overell, \& Chapple, 2011; Fernández et al., 2012). Normally, company size is significantly and positively associated with the level of voluntary disclosure (Belkaoui \& Karpik, 1989; Hackston \& Milne, 1996). More recently, several researchers have confirmed that a firm's size can play a relevant role in its CSR disclosure (Michelon \& Parbonetti, 2012; Michelon et al., 2015; Rodríguez et al., 2014).

In contrast, the relationship between profitability and voluntary disclosure is not completely clear. However, main disclosure theories, such as Agency and Political Cost theories, argue for a positive correlation (Reverte, 2009). Nevertheless, most of the empirical evidence has not found any significant results on CSR disclosure (Michelon \& Parbonetti, 2012; Rodríguez et al., 2014; Said, Zainuddin, \& Haron, 2009).

On the other hand, the responsibility for CSR disclosure decisions lies with the BD (Michelon \& Parbonetti, 2012; Rodríguez et al., 2014). This is theoretically supported by Agency (Jensen \& Meckling, 1976) and Stakeholder (Freeman, 1984) theories. According to these theories, the BD seeks to safeguard the interests of all stakeholders by disclosing information that increases transparency, thus reducing information asymmetry and avoiding opportunistic behaviors.

Based on these arguments, several researches (Amran et al., 2014; Haniffa \& Cooke, 2005; Michelon \& Parbonetti, 2012; Rodríguez et al., 2014; Said et al., 2009) have tried to identify the CG mechanisms that have an effect on CSR disclosure practices. There are several BD characteristics (BD size, level of activity of the $\mathrm{BD}$, presence of independent directors in the $\mathrm{BD}$ ), as well as other CG mechanisms (the existence of a CSR Committee in the company and the presence of a Reference Shareholder), that seem to show an effect on sustainability disclosure practices (Amran et al., 2014; Said et al., 2009).

Empirical evidence about the connection between board size and disclosure is not completely clear, although this connection seems to be related with board effectiveness. While several studies argue that smaller boards are more 
effective because having fewer members contributes to decrease communication and coordination problems (Andrés et al., 2005; Jensen, 1993; Lipton \& Lorsch, 1992; Yermack, 1996), others advocate the convenience of larger boards as these could manage more effectively the complexity of today's business environments (Frías, Rodríguez, \& García, 2013; Gandía, 2008; Kent \& Stewart, 2008; Willekens, Bauwhede, Gaeremynck, \& Gucht, 2005). This debate about effectiveness is also extended to the level of activity of BDs. In this respect, some researchers argue that more active boards would be more effective (Lipton \& Lorsch, 1992), while others have suggested that an excessive number of meetings implies less effectiveness (Vafeas, 1999).

In both cases (Board size and level of activity), BD effectiveness is closely linked to the information disclosed by companies (García, Rodríguez, \& Gallego, 2011). In other words, evidence suggests that more effective boards would disclose more information, which includes more information about CSR.

Another aspect of this governance mechanism that is commonly examined is board independence. The literature has shown board independence to be positively associated with disclosure practices since independent directors are less aligned with the management, and encourage firms to disclose more and increase information quality as an attempt to protect the interests of all stakeholders (Forker, 1992; Michelon \& Parbonetti, 2012; among others). Nevertheless, some contributions show a negative relationship (Haniffa \& Cooke, 2005; Prado \& García, 2010), while others identify a non-significant relationship (Frías et al., 2013; García et al., 2011).

According to Ullman (1985), the establishment of a CSR Committee is an obvious indication of the company's CSR engagement level. Since one of the functions of this committee is to ensure the quality of the company's sustainability disclosure, the existence of a CSR Committee can be viewed as a sign of the company's commitment to stakeholders, in line with the evidence found by Michelon and Parbonetti (2012) and Amran et al. (2014).

The last CG mechanism that the literature points as capable of affecting CSR disclosure is the existence of a Reference Shareholder (someone who has the majority of voting rights, veto power or golden share in a company). Ownership structure is identified as one of the key elements that explain international variations in the CG structure (Hoshi, Kashyap, \& Scharfstein, 1990; Porta et al., 1999). The presence of a Reference Shareholder is one of the most relevant characteristics of ownership which will certainly affect the company's strategic decisions as he/she has enough power to appoint directors to the board (Boyd, 1994). Considering that several characteristics of the BD can affect CSR reporting practices, as discussed earlier, one can see the potential influence that the existence of a Reference Shareholder would have on CSR disclosure practices.

Additionally, Agency Theory (Ross, 1973) also contribute in this line of thought as some authors argue that shareholders are more in favor of CSR than managers (Miras, Escobar, \& Carrasco, 2014) since the former are concerned about long-term repercussions and aware of the negative consequences of not being socially responsible (Graves \& Waddock, 1994; Margolis \& Walsh, 2003). Therefore, the first hypothesis is as follows:

H1: CG mechanisms have an influence on CSR reporting practices.

Furthermore, many researchers have stated the relevant role that industry plays on CSR disclosure (Fifka, 2013; Kolk \& Perego, 2010; Simnett et al., 2009; Sweeney \& Coughlan, 2008). In this respect, the main arguments affirm that the nature of activities determines the industry's attitude to social responsibility along with the need for legitimization in the markets or the need for improving firms' reputation due to the negative impact of their activities (greenwashing).

Finally, companies are also under another kind of pressure to disclose about CSR, i.e., pressure from their institutional environment (Adams, 2002; Kolk \& Perego, 2010; Lattemann, Fetscherin, Alon, Li, \& Schneider, 2009). This is theoretically supported by Institutional Theory, which states that organizations are continuously adapting their structures and policies to the institutional norms and cultural context in which they operate (Dimaggio \& Powell, 1983; Scott \& Meyer, 1994) as an attempt to survive in the markets. Apart from the influence of regulation in each institutional environment, companies will imitate the successful behavior or practices carried out by their peer organizations (Dimaggio \& Powell, 1983). This is the argument followed by North (1991) and Williamson (2000) when they try to explain the concept of institutional environment.

The most relevant evidence in the literature that enhances the existence of this relationship was highlighted by Adams (2002): (1) the strong dependence between the issues that are worthy reporting and the institutional environment; (2) the divergences found in companies' main CSR concerns also depend on the institutional environment; and (3) stakeholders' demands for firms to be socially responsible vary according to differences in the institutional environment. Considering all these arguments, our second hypothesis affirms that:

H2: CSR disclosure is different depending on the institutional environment in which the company operates.

Nevertheless, Adams (2002) pointed out the complexity of analyzing the institutional environment's influence since it is 
very difficult to isolate the contextual variables and to differ its influence from the indirect effects derived from the influence that the institutional environment has on the other internal context variables.

This brings us to consider whether the effects of the institutional environment on CSR reporting is not direct but could be explained instead by the mediation of CG mechanisms, a mediation that is strongly influenced by the institutional environment (Doidge et al., 2007; Klapper \& Love, 2004; Li \& Harrison, 2008a, 2008b) and, at the same time, significantly relevant to CSR disclosure practices (Haniffa \& Cooke, 2005; Michelon \& Parbonetti, 2012).

On the one hand, Charkham (1994) and Porta et al. (1999) remarked that one of the significant effects of the institutional environment on the internal variables of companies is the variation in corporate ownership structures. In this perspective, Klapper and Love (2004) and Doidge et al. (2007) highlighted two country-related characteristics that are determinant in the impact of institutional environment: investor protection and the costs of accessing capital markets. The empirical evidence in this respect (Li \& Harrison, 2008a, 2008b) confirms that CG structures are strongly affected by the institutional environment, particularly Board Size and Board's Independence. Consequently, our third hypothesis is as follows:

H3: Corporate Governance mechanisms are influenced by the institutional environment in which the company operates.

Considering Adams's (2002) argument regarding the difficulty to determine whether the effect of the institutional environment on CSR reporting practices is direct or if it is explained by the influence that this environment has on other internal variables - in this case the CG mechanisms - we state our fourth hypothesis:

$\mathrm{H}_{4}$ : The influence that the institutional environment has on CSR disclosure is explained by the mediating role of CG mechanisms.

Figure 1 shows the relationships between the three main variables discussed in this theoretical section as well as the theoretical framework which supports them.

Figure 1. Map of the relationships between the three main variables

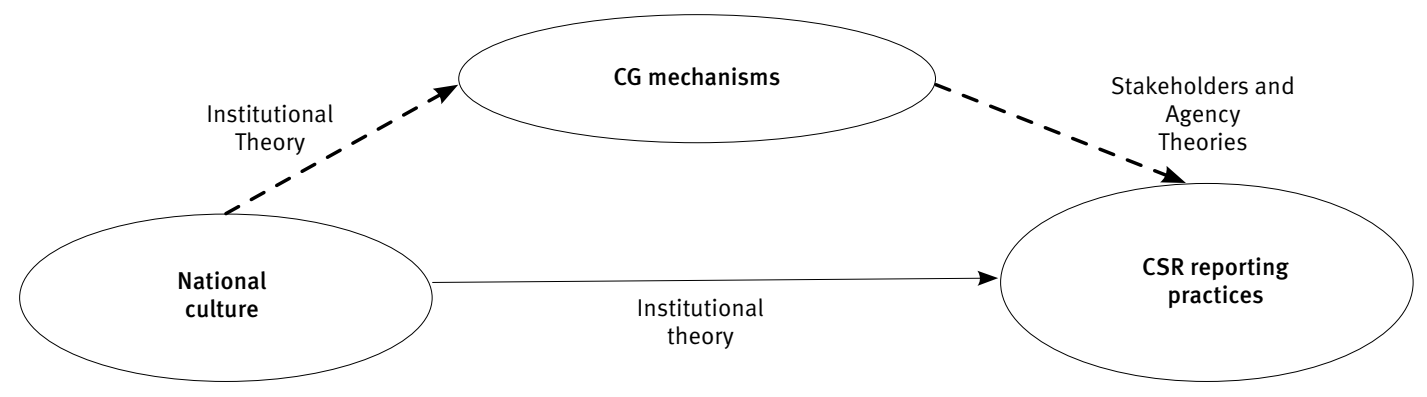

\section{METHODOLOGY}

This study is predominantly explanatory and uses a quantitative approach. In this section, the study's sample selection, variables and statistical method are explained.

\section{Country selection and sample}

Previous research about CSR disclosure has taken the institutional environment of the company into consideration in different ways. On the one hand, there are some studies that assume this influence by focusing only on one institutional environment (Gallego et al., 2014; Kuo, Yeh, \& Yu, 2012; Michelon et al.,
2015; Paul et al., 2006, Prado et al., 2009) or by controlling its effect in multinational samples (Alon, Lattemann, Fetscherin, Li, \& Schneider, 2010; Chen \& Bouvain, 2009; Fortanier, Kolk, \& Pinkse, 2011).

On the other hand, other studies try to determine the impact that different institutional environments have on CSR reporting practices (Adams, 2002; Golob \& Bartlett, 2007; Grecco et al., 2013; Tschopp, 2005; Young \& Marais, 2012). One of the characteristics of this kind of research is that it is mainly focused on developed countries, although their institutional environments vary according to two classifications: Variety of Capitalism (VOC) (Hall \& Solskic, 2001) and the Governance Index Environment (GEI) (Li \& Filer, 2007). 
The latter has allowed expanding the scope of research since it classifies each society either as a Rule-Based or a Relation-Based environment (Li, Park, \& Li, 2004). To that end, GEI considers five relevant aspects of each environment: political rights, rule of law, free press, the quality of accounting standards, and general trust levels. In Rule-Based environments, regulation is transparent and efficient, and, consequently, the information reported by companies is credible. However, the control exercised by the government in Relation-Based environments can trigger a general mistrust in the information provided, and companies feel less pressure to disclose about their practices (Lattemann et al., 2009).

Consequently, we are going to test our hypothesis focusing on the comparison between Rule-Based and Relation-Based environments, which are measured by the GEI Index (a positive score means a Rule-Based environment, while a negative one means a Relation-Based society). In order to choose the concrete institutional environments for our investigation, the CSR reporting practices were relevant, as well as the CG mechanisms. Therefore, we decided to focus on two countries with a high level of CSR reporting and a Code of Good Governance.

This is why our sample consists of Spanish and Brazilian listed companies (according with the GEl index, Brazil is identified as a Relation-Based environment, while Spain belongs to the Rule-Based group).

Both countries have been identified as pioneers in the CSR reporting field in their respective geographic regions. While Brazil has proved a leading country in Latin America in the publication of CSR reports (Gallego et al., 2014), Spain is widely recognized for its companies' CSR reporting practices (Sierra et al., 2013). Nevertheless, differences are reported in the percentage of CSR report-publishing companies and the level of GRI adoption; the assurance of CSR reports is recognized by KPMG (2013) and Grecco et al. (2013).

Additionally, the Codes of Good Governance in effect are from 2009, in the case of Brazil, and 2006, in Spain. Their main recommendations are summarized in Exhibit 1.

\section{Exhibit 1. Key characteristics of the Codes of Good Governance of Brazil and Spain}

\begin{tabular}{l|l|l}
\hline Corporate governance characteristics & Brazil & Spain \\
\hline board size & Between 5 and 11 & Between 5 and 15 \\
\hline Independent directors & Most should be independent & At least more than $33 \%$ \\
\hline Board activity & $\begin{array}{l}\text { It is suggested that the frequency of } \\
\text { meetings should not exceed one per month }\end{array}$ & No recommendation \\
\hline CSR Committee & Suggested, although not further elaborated & No recommendation \\
\hline
\end{tabular}

Source: Codes of Good Governance of Spain and Brazil.

Previous research about CG in Brazil (Black et al., 2010) pointed out the need to strengthen the BDs of Brazilian companies since they have boards too small to be effective, and a significant percentage of Brazilian boards has no independent directors at all. This problem is common to most BRICS countries (Estrin \& Prevezer, 2011). On the other hand, Andrés et al. (2005) analyzed the characteristics of BDs in OECD countries to get insights about their effectiveness. Spanish BDs are medium-sized, mostly formed by independent directors ( $75 \%$ ) and quite active ( 8.57 meetings per year).

Initially, 128 companies from Brazil and Spain were selected because of two reasons: (1) the information about their CSR disclosure practices was available at Corporate Registers, the GRI website, or, in a few cases, directly at the company's website (even when there was no formal CSR report); and (2) their CG data were available at the ASSET4 Database. This database is frequently used by academics (loannou \& Serafeim, 2012) and investors to build their sustainability reports. It provides a collection of indicators (valued from o to 100) organized in four pillars: Social Scores, Environmental Scores, Corporate Governance Scores, and Economic Scores. The financial data were provided by the DataStream database. Because some pieces of information were not available for three companies, we have to remove those companies from our sample.

Once we had our final sample composition (125 companies), we proceeded to analyze their CSR disclosure practices based on their CSR reports, annual reports or integrated reporting. This information about CSR reporting practices refers to the financial year 2012 because it was the last available year for the complete sample (the lag between the year covered and the date of publication is from 1 to 2 years - Boiral, 2013). For the cases in which there was no coincidence between the natural year and the financial year, we used the most recent report available (from 2011-2012 or 2012-2013). 


\section{Variables: Dependent, independent and control}

Exhibit 2 shows how each variable (dependent, independent and control) was measured in this study.

Exhibit 2. Measurement of variables

\begin{tabular}{|c|c|c|c|}
\hline & Variable & Measurement & Source \\
\hline \multirow{4}{*}{$\begin{array}{l}\text { Dependent } \\
\text { variable }\end{array}$} & \multirow{4}{*}{ CSR index } & (1) CSR information in a report & Gray, Kouhy, \& Lavers (1995) \\
\hline & & (2) GRI adoption level & Adams (2002), Boiral (2013) \\
\hline & & (3) Externally checked & $\begin{array}{l}\text { Prado, Gallego, \& García (2009), Fernández, } \\
\text { Romero, \& Ruiz (2012) }\end{array}$ \\
\hline & & (4) Assurance of the CSR report & $\begin{array}{l}\text { Simnett, Vanstraelen, \& Chua (2009), Fernández, } \\
\text { Romero, \& Ruiz (2014) }\end{array}$ \\
\hline \multirow{5}{*}{$\begin{array}{l}\text { Corporate } \\
\text { governance }\end{array}$} & Board size & Number of directors & De Andrés et al. (2005); García et al. (2011) \\
\hline & $\begin{array}{l}\text { Independent } \\
\text { directors }\end{array}$ & Percentage of independent directors & Haniffa \& Cooke (2005); Prado \& García (2010) \\
\hline & Board activity & Number of board meetings & Rodríguez et al. (2014) \\
\hline & CSR committee & $\begin{array}{l}\text { Existence of a CSR committee. Dummy } \\
\text { variable. Indicator variable is one if there is a } \\
\text { CSR committee and zero otherwise }\end{array}$ & $\begin{array}{l}\text { Michelon \& Parbonetti (2012); Amran et al. } \\
\text { (2014) }\end{array}$ \\
\hline & $\begin{array}{l}\text { Reference } \\
\text { shareholder }\end{array}$ & $\begin{array}{l}\text { If the company is owned by a reference } \\
\text { shareholder who has the majority of voting } \\
\text { rights, veto power or golden share. Dummy } \\
\text { variable. Indicator variable is one if there is a } \\
\text { reference shareholder and zero otherwise }\end{array}$ & Miras et al. (2014) \\
\hline \multirow{3}{*}{ Control } & Company size & Logarithm of total assets & $\begin{array}{l}\text { Said, Zainuddin, \& Haron (2009), Amran, Lee, \& } \\
\text { Devi (2014) }\end{array}$ \\
\hline & Profitability & ROA & $\begin{array}{l}\text { Michelon \& Parbonetti (2012) Rodríguez et al. } \\
\text { (2014) }\end{array}$ \\
\hline & Industry & Industry & $\mathrm{ASSET}_{4}$ data \\
\hline
\end{tabular}

Based on previous literature about the types of CSR disclosure practices and their complexity, we used the "CSR Index" which reflects how complex the CSR reporting practices are in each company. The index consists of four items (dummy variables) that are shown in Exhibit 2.

As independent variables, we focused on the CG characteristics that have shown an influence on CSR reporting according to the literature: Board Size, Board Independence,
Board Activity, CSR Committee, and Reference Shareholder. The institutional environment was operationalized through a dummy variable. This is because there are only two countries involved, and the aim of this study is to compare them, rather than go further into the origin of differences.

Moreover, we included several control variables related to the nature of the company, such as size, profitability, and the industry, based on previous findings. 


\section{Regressions and models}

Considering the characteristics of our dependent variables (categorical, although the differences between them are not quantified), we had to use ordinal regression to get consistent results. Although other, more complex methodologies could be used (such as Structural Equation Models -SEM), we have decided to use the ordinal regression technique since (1) there were not many hypotheses and variables included, and (2) the variables were observable and not composed of several items.

Ordinal regression minimizes the differences of the sum of the squares between the dependent variable and a weighted combination of the independent variables. The estimated coefficients reflect how changes in the factors affect the level of complexity of the CSR reporting practices analyzed.

Therefore, we estimate our models:

1. CSR reporting practices $=B_{1}+\beta_{2}$ Institutional Environment $+\beta_{3}$ Company Size $+\beta_{4} R O A+$ Industry effect $+\varepsilon$

2. CSR reporting practices $=\beta_{1}+\beta_{2}$ Board Size $+\beta_{3}$ Board Independence $+\beta_{4}$ Board Activity $+\beta_{5}$ CSR Committee+ $\beta_{6}$ Reference Shareholder $+\beta_{7}$ Company Size $+\beta_{8}$ ROA + Industry effect $+\varepsilon$

3. CSR reporting practices $=\beta_{1}+\beta_{2}$ Board Size $+\beta_{3}$ Board Independence $+\beta_{4}$ Board Activity $+\beta_{5}$ CSR Committee $+\beta_{6}$ Reference Shareholder $+\beta_{7}$ Institutional Environment $+\beta_{8}$ Company Size $+\beta_{9} R O A+$ Industry effect $+\varepsilon$

Goodness of fit was determined by the -2 log of likelihood (measured through a $\mathrm{x}^{2}$ distribution) which controls the representativeness of each of the equations. If the probability value associated was below 0.05 , we should reject the null hypothesis, accepting that the final ordinal model is relevant from the econometric point of view (Hair, Black, Babin, \& Anderson, 1998).

\section{RESULTS AND DISCUSSION}

\section{Descriptive statistics}

We present the sample's distribution of industries by country (Table 1), the sample's descriptive statistics for each country (Table 2), and the bivariate correlations between all the variables included in the study (Table 4).
Table 1. Distribution of industries by country

\begin{tabular}{|c|c|c|}
\hline Industries & Brazil & Spain \\
\hline Aerospace and defense & 1.2 & \\
\hline Alternative energy & 1.2 & $4 \cdot 9$ \\
\hline Banks & 6.0 & 14.6 \\
\hline Chemicals & 1.2 & \\
\hline Construction and materials & 2.4 & $7 \cdot 3$ \\
\hline Electricity & $14 \cdot 3$ & 9.8 \\
\hline Electronic and electrical equipment & 1.2 & \\
\hline Financial services & 6.0 & $4 \cdot 9$ \\
\hline Fixed line telecommunications & 2.4 & 2.4 \\
\hline Food and drug retailers & 2.4 & 2.4 \\
\hline Food producers & 7.1 & $4 \cdot 9$ \\
\hline Forestry and paper & 2.4 & \\
\hline Gas, water and multi-utilities & 3.6 & $4 \cdot 9$ \\
\hline General industrials & 1.2 & \\
\hline General retailers & 7.1 & 2.4 \\
\hline Health care equipment and services & 2.4 & \\
\hline Household goods and home construction & 2.4 & \\
\hline Industrial engineering & 1.2 & 2.4 \\
\hline Industrial metals and mining & 6.0 & 2.4 \\
\hline Industrial transportation & 4.8 & 2.4 \\
\hline Media & 1.2 & $7 \cdot 3$ \\
\hline Mining & 1.2 & \\
\hline Mobile telecommunications & 1.2 & \\
\hline Nonlife insurance & 3.6 & 2.4 \\
\hline Oil and gas producers & 3.6 & 2.4 \\
\hline Oil equipment and services & & 2.4 \\
\hline Personal goods & 2.4 & \\
\hline Pharmaceuticals and biotechnology & & $7 \cdot 3$ \\
\hline Real estate investment and services & 7.1 & 2.4 \\
\hline Software and computer services & 1.2 & 2.4 \\
\hline Support services & & $4 \cdot 9$ \\
\hline Tobacco & 1.2 & \\
\hline Travel and leisure & 1.2 & 2.4 \\
\hline Total & 100.0 & 100.0 \\
\hline
\end{tabular}

Source: Based on ASSET4 
As shown in Table 1, the two main industries in both countries are energy (22.7\% for Brazil, $22 \%$ for Spain) and financial services (13.2\% for Brazil, 19.5\% for Spain). With regard to the representation of other sectors, Brazilian companies are more dedicated to industries and real estate investments, while the percentage of Spanish companies is higher for construction, media, and pharmacy and biotechnology. Other industries have little presence in both samples.

Table 2. Descriptive statistics for Spain and Brazil

\begin{tabular}{|c|c|c|c|c|c|c|}
\hline & \multicolumn{3}{|c|}{ Spain } & \multicolumn{3}{|c|}{ Brazil } \\
\hline & $\mathbf{N}$ & Mean & $\begin{array}{l}\text { Standard } \\
\text { deviation }\end{array}$ & $\mathbf{N}$ & Mean & $\begin{array}{l}\text { Standard } \\
\text { deviation }\end{array}$ \\
\hline CSR index & 41 & 2.78 & 1.60 & 84 & 2.06 & 1.65 \\
\hline CSR information disclosure & 41 & 0.82 & 0.38 & 84 & 0.70 & 0.46 \\
\hline GRI level & 41 & 0.71 & 0.46 & 84 & 0.58 & 0.49 \\
\hline Externally checked & 41 & 0.63 & 0.49 & 84 & 0.42 & 0.49 \\
\hline Assurance & 41 & 0.61 & 0.49 & 84 & 0.36 & 0.48 \\
\hline Board size & 41 & 14.05 & 3.47 & 84 & $9 \cdot 38$ & 2.53 \\
\hline Independent members (\%) & 40 & 30.30 & 23.09 & 67 & 25.66 & 21.96 \\
\hline BD activity & 38 & 10.79 & 3.67 & 39 & 15.21 & $13 \cdot 59$ \\
\hline CSR committee & 41 & 0.78 & 0.42 & 84 & 0.69 & 0.47 \\
\hline Reference shareholder & 41 & 0.27 & 0.44 & 84 & 0.48 & 0.50 \\
\hline ROA & 41 & $4 \cdot 72$ & 9.68 & 84 & 6.38 & $7 \cdot 91$ \\
\hline Company size & 41 & 80008608.05 & 218109043.63 & 84 & 71921260.05 & 199570754.21 \\
\hline
\end{tabular}

Source: Based on ASSET4.

Based on the descriptive statistics shown in Table 2, we can see that Spanish companies have higher scores for all CSR disclosure practices than Brazilian companies. Nevertheless, these data have to be carefully considered and complemented with others analyses (Graph 1), since the distribution could not be uniform.

\section{Graph 1. Accumulated percentage of CSR disclosure practices in Brazil and Spain}

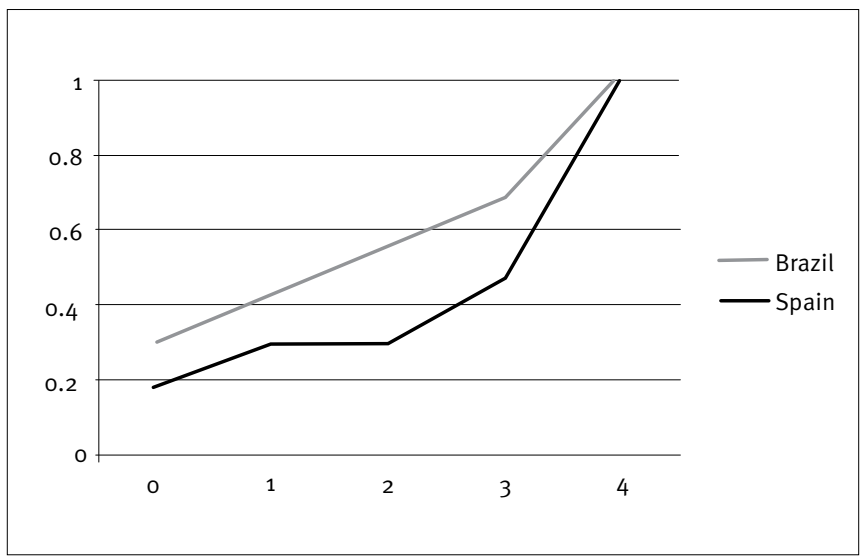

Graph 1 presents the differences found between Brazil and Spain concerning CSR disclosure practices. Mean results in Table 1 are distorted since there is a large group of Spanish companies with the maximum score: $\mathbf{5 2 . 2 8 \%}$ in the case of the CSR Index. Nevertheless, intermediate scores for Spanish companies are almost non-existent. Furthermore, $18.18 \%$ of Spanish companies do not carry out any CSR disclosure practice, nor do $29.59 \%$ follow the GRI guidelines. With regard to the assurance of CSR reports, results show that this particular CSR disclosure practice is more common in Spanish companies than in Brazilian ones, in line with the results of the survey conducted by KPMG (2013). For Brazilian companies, these percentages are higher (30.12\%). However, the CSR Index for Brazilian companies is better distributed, and not so concentrated on the maximum level.

Based on the comparison of results in Table 2 regarding financial measures, we can affirm that the Financial Performance of Brazilian companies is higher. Additionally, if we consider total assets, Spanish companies are larger than Brazilian ones.

The mean values for both countries' CG characteristics are also shown in Table 2. Indeed, one must consider that 
each country's Code of Good Governance gathers several recommendations about CG mechanisms (see Exhibit 1). Although the recommendations in Brazilian Code seem to go further than those in the Spanish Code, this is not reflected in our descriptive statistics. Spanish boards are larger, with a higher percentage of independents directors, and less active than the boards of Brazilian companies. With regard to the existence of a CSR Committee, more Spanish companies have one. As for the presence of a Reference Shareholder, there are more Brazilian than Spanish companies with a Reference Shareholder ( $48 \%$ vs $27 \%)$.

Additionally, we conducted a test of mean differences to find out which CG variables were most affected by the institutional environment (Table 3). In this case, Board Size and the existence of a Reference Shareholder are the ones showing significant statistical differences. Taking these results into account, we could accept our third hypothesis. However, it is necessary to note that not all CG mechanisms show significant statistical differences (only Board Size and Reference Shareholder).
Table 3. Test of mean differences for CG characteristics

\begin{tabular}{l|l}
\hline Corporate Governance characteristics & Test of mean differences \\
\hline Board size & $55.38^{\star *}$ \\
\hline Independent directors & 52.99 \\
\hline Board activity & 19.33 \\
\hline CSR committee & 1.60 \\
\hline Reference shareholder & $6.16 *$ \\
\hline
\end{tabular}

Significance test **< $0.005, *<0.05$

Source: Based on ASSET4

As shown in Table 4, there is a significant, positive correlation between CSR reporting practices and three of the independent variables (Board Size, CSR Committee and Reference Shareholder). These results support that CSR disclosure decisions lie with BDs (Adams, 2002; Haniffa \& Cooke, 2005; Michelon \& Parbonetti, 2012).

Table 4. Bivariate correlations

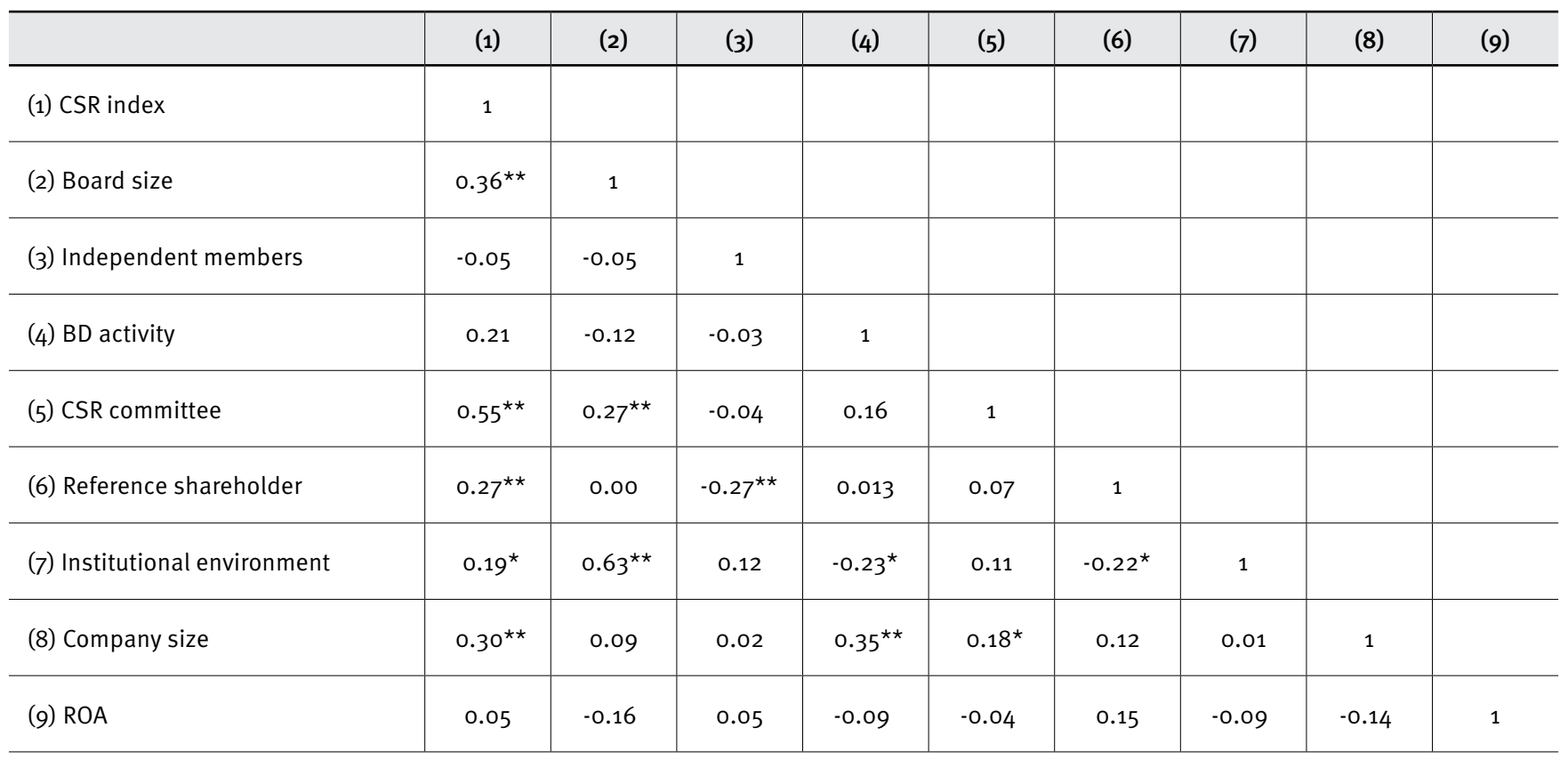

Significance test $* *<0.01 *<0.05$

Source: Based on ASSET 4

With regard to CG variables, we could only find two significant correlations: Board size - CSR Committee (positive); and Independent Members - Reference Shareholder (negative). This evidence is logical and consistent with Boyd's (1994) argument that when there is a Reference Shareholder, several directors will be appointed by him/her.

\section{Multivariate tests}

All models in the study are statistically relevant according to their statistics (-2-log-likelihood), and their results are summarized in Tables 5 and 6. Firstly, it is worth highlighting that the institutional environment has a strongly significant influence on the complexity 
of CSR disclosure practices when they are studied separately (see Table 5). This was expected, according with theoretical the framework and previous empirical evidence (Adams, 2002; Grecco et al., 2013; Kolk \& Perego, 2010; Young \& Marais, 2012). Therefore, Hypothesis 2 is accepted.

\section{Table 5. Comparison of results of the ordinal regression}

\begin{tabular}{|c|c|c|c|c|c|c|}
\hline & \multicolumn{3}{|c|}{ Brazil } & \multicolumn{3}{|c|}{ Spain } \\
\hline & $\begin{array}{l}\text { Coefficient } \\
\text { estimation }\end{array}$ & $\begin{array}{l}\text { Standard } \\
\text { deviation }\end{array}$ & Wald & $\begin{array}{l}\text { Coefficient } \\
\text { estimation }\end{array}$ & $\begin{array}{l}\text { Standard } \\
\text { deviation }\end{array}$ & Wald \\
\hline Company size & 2.07 & 0.46 & $19.95^{\star \star}$ & -0.90 & 0.73 & 1.53 \\
\hline ROA & 0.96 & 0.05 & $4.62^{*}$ & 0.47 & 0.24 & $3.87^{\star}$ \\
\hline Industry & \multicolumn{3}{|c|}{ controlled } & \multicolumn{3}{|c|}{ controlled } \\
\hline-2 log likelihood & \multicolumn{3}{|c|}{$157 \cdot 71$} & \multicolumn{3}{|c|}{42.51} \\
\hline$x^{2}$ & \multicolumn{3}{|c|}{$97 \cdot 51^{\star \star}$} & \multicolumn{3}{|c|}{$54 \cdot 39^{\star \star}$} \\
\hline Pseudo R² Cox \& Snell & \multicolumn{3}{|c|}{0.69} & \multicolumn{3}{|c|}{0.74} \\
\hline
\end{tabular}

Significance test **<0.005, * $<0.05$

Source: Based on ASSET4

Once these first analyses were finished, we focused on the ordinal regressions of the models proposed (Table 6). Firstly, we found that including CG variables has a positive impact on the explanation of CSR report complexity ( $\mathrm{R}^{2}$ increases). Therefore, we conclude that CG characteristics affect CSR disclosure (i.e., Hypothesis 1 is accepted). These results are in line with previous evidence in this respect.

\section{Table 6. Results of the ordinal regressions}

\begin{tabular}{|c|c|c|c|c|c|c|c|c|c|}
\hline & \multicolumn{9}{|c|}{ CSR Index } \\
\hline & \multicolumn{3}{|c|}{ Model 1} & \multicolumn{3}{|c|}{ Model 2} & \multicolumn{3}{|c|}{ Model 3} \\
\hline & $\begin{array}{l}\text { Coefficient } \\
\text { estimation }\end{array}$ & $\begin{array}{l}\text { Standard } \\
\text { deviation }\end{array}$ & Wald & $\begin{array}{l}\text { Coefficient } \\
\text { estimation }\end{array}$ & $\begin{array}{l}\text { Standard } \\
\text { deviation }\end{array}$ & Wald & $\begin{array}{l}\text { Coefficient } \\
\text { estimation }\end{array}$ & $\begin{array}{l}\text { Standard } \\
\text { deviation }\end{array}$ & Wald \\
\hline Board size & & & & 0.33 & 0.16 & $4.42 t$ & 0.11 & 0.22 & 0.25 \\
\hline $\begin{array}{l}\text { Independent } \\
\text { directors }\end{array}$ & & & & 0.02 & 0.02 & 1.18 & 0.01 & 0.02 & 0.52 \\
\hline Board activity & & & & -0.16 & 0.11 & 2.02 & -0.17 & 0.12 & 2.26 \\
\hline CSR committee & & & & 1.52 & 1.10 & 1.94 & 1.79 & 1.16 & 2.41 \\
\hline $\begin{array}{l}\text { Reference } \\
\text { shareholder }\end{array}$ & & & & 1.98 & 1.06 & $3 \cdot 50^{\star}$ & 2.52 & 1.17 & $4.62^{*}$ \\
\hline $\begin{array}{l}\text { Institutional } \\
\text { environment }\end{array}$ & -1.86 & 0.53 & $12.11^{\star \star}$ & & & & -2.07 & 1.49 & 1.91 \\
\hline Company size & 1.21 & 0.23 & $26.96^{\star \star}$ & 2.03 & 0.58 & $12.33^{\star \star}$ & 2.19 & 0.65 & $11.35^{\star \star}$ \\
\hline ROA & 0.09 & 0.03 & $6.21^{\star}$ & 0.30 & 0.13 & $5.62^{\star}$ & 0.29 & 0.13 & $5 \cdot 30^{*}$ \\
\hline Industry & \multicolumn{3}{|c|}{ controlled } & \multicolumn{3}{|c|}{ controlled } & \multicolumn{3}{|c|}{ controlled } \\
\hline-2 log likelihood & \multicolumn{3}{|c|}{261.38} & \multicolumn{3}{|c|}{91.95} & \multicolumn{3}{|c|}{89.85} \\
\hline$x^{2}$ & \multicolumn{3}{|c|}{$103 \cdot 52^{\star \star}$} & \multicolumn{3}{|c|}{$83.74^{\star \star}$} & \multicolumn{3}{|c|}{$85.84^{\star \star}$} \\
\hline $\begin{array}{l}\text { Pseudo R² Cox \& } \\
\text { Snell }\end{array}$ & \multicolumn{3}{|c|}{0.56} & \multicolumn{3}{|c|}{0.70} & \multicolumn{3}{|c|}{0.71} \\
\hline
\end{tabular}

Significance test ${ }^{* *}<0.005, *<0.05$, †<0.1

Source: Based on ASSET4 
However, not all CG mechanisms have a statistical significant effect on the dependent variable. Board Size and the existence of a Reference Shareholder are the CG mechanisms that positively affect CSR disclosure. These results are in line with the scarce literature on this subject matter (Young \& Marais, 2012). Previous research has pointed out that the presence of independent directors in boards has a positive effect on the level of CSR disclosure (Lattemann et al., 2009), although we did not confirm this in our findings. This disagreement could be explained by the low percentage of external directors in the companies included in the sample.

The empirical evidence suggests that the CG mechanisms with a strong influence on CSR reporting practices (Board Size and Reference Shareholder) are the ones that show significant differences according to the institutional environment (see Table 3).

When the impacts of CG mechanisms and institutional environment on CSR reporting practices were considered simultaneously, we found that the institutional environment was no longer significant. The goodness of fit of this model is quite close to that of the model which did not consider the institutional environment (only a $1 \%$ increase). Only one of the CG variables (the existence of a Reference Shareholder) continued showing a significant influence on CSR disclosure.

At this point, we were able to conclude that the influence of the institutional environment on CSR disclosure is mediated by both CG mechanisms (Board Size and Reference Shareholder). Therefore, Hypothesis 4 is accepted.

With regard to the control variables (size and ROA), our results confirmed that company size and profitability have a positive impact on the complexity of CSR disclosure practices, although in some cases, the significance of that impact decreased when CG variables were included in the models. All regressions were also controlled by industry.

\section{CONCLUSIONS}

Considering that the aim of this paper is to analyze whether the effect of the institutional environment on CSR reporting practices is direct or if this effect can be explained by the influence that the institutional environment has on CG mechanisms, we can conclude that CG mechanisms mediate the influence that the institutional environment has on CSR reporting practices. Not all CG characteristics were found to be determinant, i.e., only Board Size and the existence of a Reference Shareholder were found to have a significant impact on the complexity of those reporting practices.
This research reveals that it is strongly relevant to know and study the regulation and recommendations concerning CG-related issues for each country (which are reflected on each country's Code of Good Governance) as well as their actual implementation in companies since CG features could be decisive for several strategic decisions, particularly policies of voluntary disclosure.

Specifically, our study focused on comparing two institutional environments (Rule-Based and Relation-based). Our results support that CSR disclosure complexity is higher in RuleBased institutional environments.

The main contribution of this study is our finding that the higher complexity of the CSR information disclosed in Rule-Based societies comes from the effect of these societies' institutional environment on CG mechanisms. Therefore, as Relation-Based societies evolve into Rules-Based environments, the information disclosed about Corporate Social Responsibility becomes more complex due to a strengthening of Corporate Governance mechanisms.

Our results suggest that further investigations should be conducted including more countries in the sample. Moreover, future research on this topic might consider using other statistical techniques such as SEM.

\section{REFERENCES}

Adams, C. A. (2002). Internal organizational factors influencing corporate social and ethical reporting. Accounting, Auditing \& Accountability Journal, 15(2), 223-250. doi:10.1108/09513570210418905

Alon, I., Lattemann, C., Fetscherin, M., Li, S., \& Schneider, A. M. (2010). Usage of public corporate communications of social responsibility in Brazil, Russia, India and China (BRIC). International Journal of Emerging Markets, 5(1), 6-22. doi:10.1108/17468801011018248

Amran, A., Lee, S. P., \& Devi, S. S. (2014). The influence of governance structure and strategic corporate social responsibility toward sustainability reporting quality. Business Strategy and the Environment, 23(4), 217-235. doi:10.1002/bse.1767

Andrés, P. De, Azofra, V., \& Lopez, F. (2005). Corporate boards in OECD countries: Size, composition, functioning and effectiveness. Corporate Governance: An International Review, 13(2), 197-210. doi:10.1111/ j.1467-8683.2005.00418.x

Belkaoui, A., \& Karpik, P. G. (1989). Determinants of the corporate decision to disclose social information. Accounting, Auditing \& Accountability Journal, 2(1), 36-51. doi:10.1108/09513578910132240

Black, B. S., Carvalho, A. G. De, \& Gorga, E. (2010). Corporate governance in Brazil. Emerging Markets Review, 11(1), 21-38. doi:10.1016/j. ememar.2009.09.004

Boiral, O. (2013). Sustainability reports as simulacra? A counter-account of A and A+ GRI reports. Accounting, Auditing \& Accountability Journal, 26(7), 1036-1071. doi:10.1108/AAAJ-04-2012-00998

Boyd, B. K. (1994). Board control and CEO compensation. Strategic Management Journal, 15, 335-344. 
Bushman, R., Piotroski, J. D., \& Smith, A. J. (2004). What determines corporate transparency? Journal of Accounting Research, 42(2), 207-252. doi:10.1111/j.1475-679x.2004.00136.x

Castelo, M., Delgado, C., Ferreira, S., \& Pereira, T. (2014). Factors influencing the assurance of sustainability reports in the context of the economic crisis in Portugal. Managerial Auditing Journal, 29(3), 237252. doi:10.1108/MAJ-07-2013-0905

Charkham, J. (1994). Keeping good company: A study of corporate governance in five countries. Oxford, United Kingdom: Clarendon Press.

Chen, S., \& Bouvain, P. (2009). Is corporate responsibility converging? A comparison of corporate responsibility reporting in the USA, UK, Australia, and Germany. Journal of Business Ethics, 87(1), 299-317. doi:10.1007/s10551-008-9794-0

Clarkson, P. M., Overell, M. B., \& Chapple, L. (2011). Environmental reporting and its relation to corporate environmental performance. Abacus, 47(1), 27-60. doi:10.1111/j.1467-6281.2011.00330.x

Crowther, D. (2000). Corporate reporting, stakeholders and the internet: Mapping the new corporate landscape. Urban Study, 37(10), 18371848. doi:10.1080/00420980020080451

Dimaggio, P. J., \& Powell, W. W. (1983). The iron cage revisited: Institutional isomorphism and collective rationality in organizational fields. American Sociological Review, 48(2), 147-160.

Doidge, C., Karolyi, A., \& Stulz, R. M. (2007). Why do countries matter so much for corporate governance? Journal of Financial Economics, 86(1), 1-39. doi:10.1016/j.jfinec0.2006.09.002

Elkington, J. (1998). Partnerships from cannibals with forks: The triple bottom line of 21st century business. Environmental Quality Management, 8(1), 37-51. doi:10.1002/tqem.3310080106

Estrin, S., \& Prevezer, M. (2011). The role of informal institutions in corporate governance: Brazil, Russia, India, and China compared. Asia Pacific Journal of Management, 28(1), 41-67. doi:10.1007/s10490010-9229-1

Fernández, B., Romero, S., \& Ruiz, S. (2012). Measuring quality of sustainability reports and assurance statements: Characteristics of the high quality reporting companies. International Journal of Society Systems Science, 4(1), 5-27. doi:10.1504/ijsss.2012.045371

Fernández, B., Romero, S., \& Ruiz, S. (2014). Effect of stakeholders' pressure on transparency of sustainability reports within the GRI framework. Journal of Business Ethics, 122(1), 53-63. doi:10.1007/ S10551-013-1748-5

Fifka, M. S. (2013). Corporate responsibility reporting and its determinants in comparative perspective-a review of the empirical literature and a meta-analysis. Business Strategy and the Environment, 22(1), 1-35. doi:10.1002/bse.729

Forker, J. J. (1992). Corporate governance and disclosure quality. ACcounting and Business Research, 22, 111-124. doi:10.1080/0001478 8.1992.9729426

Fortanier, F., Kolk, A., \& Pinkse, J. (2011). Harmonization in CSR reporting. Management International Review, 51(5), 665-696. doi:10.1007/ S11575-011-0089-9

Freeman, R. E. (1984). Strategic management: A stakeholder approach. Boston, USA: Pitman.

Frías, J. V., Rodríguez, L., \& García, I. M. (2013). The role of the board in the dissemination of integrated corporate social reporting. Corporate Social Responsibility and Environmental Management, 20, 219-233. doi:10.1002/csr.1294

Gallego, I., Formigoni, H., \& Antunes, M. T. P. (2014). Corporate social responsibility practices at Brazilian firms. RAE-Revista de Administração de Empresas, 54(1), 12-27. doi:10.1590/s0034-759020140103
Gandía, J. L. (2008). Determinants of interest-based corporate governance disclosure by Spanish listed companies. Online Information Review, 32(6), 791-817. doi:10.1108/14684520810923944

García, I. M., Rodríguez, L., \& Gallego, I. (2011). Corporate governance and strategic information on the internet. Accounting, Auditing \& Accountability Journal, 24(4), 471-501. doi:10.1108/09513571111133063

García, M. A., Sierra, L., \& Zorio, A. (2013). Financial crisis impact on sustainability reporting, Management Decision, 51(7), 1528-1542. doi:10.1108/md-03-2013-0102

Golob, U., \& Bartlett, J. L. (2007). Communicating about corporate social responsibility: A comparative study of CSR reporting in Australia and Slovenia. Public Relations Review, 33(1), 1-9. doi:10.1016/j. pubrev.2006.11.001

Graves, S. B., \& Waddock, S. A. (1994). Institutional owners and corporate social performance. Academy of Management Journal, 37(4), 1034-1046. doi:10.2307/256611

Gray, R. H., Kouhy, R., \& Lavers, S. (1995). Constructing a research database of social and environmental reporting by UK companies. Accounting, Auditing \& Accountability Journal, 8(2), 78-101. doi:10.1108/09513579510086812

Grecco, M. C. P., Filho, M. A. F. M., Segura, L. C., García, I. M., \& Rodríguez, L. (2013). The voluntary disclosure of sustainable information: A comparative analysis of Spanish and Brazilian companies. Revista de Contabilidade e Organizações, 7(17), 45-55. 10.11606/rco. v7i17.5669o

Hackston, D., \& Milne, M. J. (1996). Some determinants of social and environmental disclosures in New Zealand companies. Accounting, Auditing \& Accountability Journal, 9(1), 77-108. doi:10.1108/09513579610109987

Hair, J. F., Black, W. C., Babin, B. J., \& Anderson, R. E. (1998). Multivariate data analysis. New Jersey, USA: Prentice-Hall.

Hall, P., \& Solskice, D. (2001). Varieties of capitalism: The institutional foundations of comparative advantage. Oxford, USA: Oxford University Press.

Haniffa, R. M., \& Cooke, T. E. (2005). The impact of culture and governance on corporate social reporting. Journal of Accounting and Public Policy, 24(5), 391-430. doi:10.1016/j.jaccpubpol.2005.06.001

Hoshi, T., Kashyap, A., \& Scharfstein, D. (1990). The role of banks in reducing the costs of financial distress in Japan. Journal of Financial Economics, 27(1), 67-88. doi:10.1016/0304-405X(90)90021-Q

Ihlen, Ø., Bartlett, J., \& May, S. (2011). The handbook of communication and corporate social responsibility. USA: John Wiley \& Sons.

Ioannou, I, \& Serafeim, G. (2012). What drives corporate social performance? The role of nation-level institutions. Journal of International Business Studies, 43(9), 834-864. doi:10.1057/jibs.2012.26

Jensen, M. C. (1993). The modern industrial revolution, exit, and the failure of internal control systems. The Journal of Finance, 48(3), 831880. doi:10.1111/j.1540-6261.1993.tbo4022.x

Jensen, M. C., \& Meckling, H. W. (1976). Theory of the firm: Managerial behavior, agency costs, and ownership structure. Journal of Financial Economics, 3(4), 305-360. doi:10.1016/0304-405x(76)90026-x

Kent, P., \& Stewart, J. (2008). Corporate governance and disclosures on the transition to international financial reporting standards. Accounting and Finance, 48(4), 649-671. doi:10.1111/j.1467629x.2007.00257.x

Klapper, L. F., \& Love, I. (2004). Corporate governance, investor protection, and performance in emerging markets. Journal of Corporate Finance, 10(5), 703-728. doi:10.1016/So929-1199(03)00046-4 
Kolk, A., \& Perego, P. (2010). Determinants of the adoption of sustainability assurance statements: An international investigation. Business Strategy and the Environment, 19(3), 182-198. doi:10.1002/bse.643

KPMG. (2011). KPMG international survey of corporate responsibility reporting 2011. Amsterdam, Netherlands: KPMG International Global Sustainability Services.

KPMG. (2013). KPMG international survey of corporate responsibility reporting 2013. Amsterdam, Netherlands: KPMG International Global Sustainability Services.

Kuo, L., Yeh, C. C., \& Yu, H. C. (2012). Disclosure of corporate social responsibility and environmental management: Evidence from China. Corporate Social Responsibility and Environmental Management, 19(5), 273-287. doi:10.1002/csr.274

Lattemann, C., Fetscherin, M., Alon, I., Li, S., \& Schneider, A. M. (2009). CSR communication intensity in Chinese and Indian multinational companies. Corporate Governance: An International Review, 17(4), 426-442. doi:10.1111/j.1467-8683.2009.00758.x

Lee, M. D. P. (2008). A review of the theories of corporate social responsibility: Its evolutionary path and the road ahead. International Journal of Management Reviews, 10(1), 53-73. doi:10.1111/j.1468 2370.2007.00226.x

Li, S., \& Filer, L. (2007). The effects of the governance environment on the choice of investment mode and the strategic implications. Jour nal of World Business, 42(1), 80-98. doi:10.1016/j.jwb.2006.11.006

Li, J., \& Harrison, J. R. (2008a). National culture and the composition and leadership structure of boards of directors. Corporate Governance: An International Review, 16(5), 375-385. doi:10.1111/j.14678683.2008.00697.x

Li, J., \& Harrison, J. R. (2008b). Corporate governance and national culture: A multi-country study. Corporate Governance, 8(5), 607-621. doi:10.1108/14720700810913278

Li, S., Park, S. H., \& Li, S. (2004). The great leap forward: The transition from relation-based governance to rule-based governance. Organizational Dynamics, 33(1), 63-78. doi:10.1016/j.orgdyn.2003.11.005

Lipton, M., \& Lorsch, J. W. (1992). A modest proposal for improved corporate governance. Business Lawyer, 48(1), 59-77.

Margolis, J. D., \& Walsh, J. P. (2003). Misery loves companies: Rethinking social initiatives by business. Administrative Science Quarterly, 48(2), 268-305. doi:10.2307/3556659

Michelon, G., \& Parbonetti, A. (2012). The effect of corporate governance on sustainability disclosure. Journal of Management and Governance, 16(3), 477-509. doi:10.1007/s10997-010-9160-3

Michelon, G., Pilonato, S., \& Ricceri, F. (2015). CSR reporting practices and the quality of disclosure: An empirical analysis. Critical Perspectives on Accounting, 33, 59-78. doi:10.1016/j.cpa.2014.10.003

Miras, M. M., Escobar, B., \& Carrasco, A. (2014). Are Spanish listed firms betting on CSR during the crisis? Evidence from the agency problem. Business and Management Research, 3(1), 85-95. doi:10.5430/bmr. v3n1p85

North, D. (1991). Institutions. Journal of Economic Perspectives, 5(1), 97-112.

Paul, K., Cobas, E., Ceron, R., Frithiof, M., Maass, A., Navarro, I., ... Deaton, L. Z. (2006). Corporate social reporting in Mexico. Journal of Corporate Citizenship, 22, 67-80. doi:10.9774/gleaf.4700.2006. su.00007

Perego, P., \& Kolk, A. (2012). Multinationals' accountability on sustainability: The evolution of third-party assurance of sustainability reports. Journal of Business Ethics, 110(2), 173-190. doi:10.1007/ S10551-012-1420-5
Porta, R. La, Lopez-De-Silanes, F., \& Shleifer, A. (1999). Corporate ownership around the world. Journal of Finance, 54(2), 471-517. doi:10.1111/0022-1082.00115

Prado, J. M., Gallego, I., \& García, I. M. (2009). Stakeholder engagement and corporate social responsibility reporting: The ownership structure effect. Corporate Social Responsibility and Environmental Management, 16(2), 94-107. doi:10.1002/csr.189

Prado, J. M., \& García, I. M. (2010). The role of the board of directors in disseminating relevant information on greenhouse gases. Journal of Business Ethics, 97(3), 391-424. doi:10.1007/s10551-010-0515-0

Reverte, C. (2009). Determinants of corporate social responsibility disclosure ratings by Spanish listed firms. Journal of Business Ethics, 88(2), 351-366

Rodríguez, L., Frías, J. V., \& García, R. (2014). El consejo de administración y las memorias de sostenibilidad. Revista de Contabilidad-Spanish Accounting Review, 17(1), 5-16. doi:10.1016/j.rcsar.2013.02.002

Ross, S. A. (1973). The economic theory of agency: The principal's problem. The American Economic Review, 63(2), 134-139.

Said, R., Zainuddin, Y. H., \& Haron, H. (2009). The relationship between corporate social responsibility disclosure and corporate governance characteristics in Malaysian public listed companies. Social Responsibility Journal, 5(2), 212-226. doi:10.1108/17471110910964496

Scott, W. R., \& Meyer, J. W. (1994). Institutional environments and organizations: Structural complexity and individualism. Thousand Oaks, CA: Sage.

Sierra, L., Zorio, A., \& García, M. A. (2013). Sustainable development and assurance of corporate social responsibility reports published by Ibex-35 companies. Corporate Social Responsibility and Environmental Management, 20(6), 359-370. doi:10.1002/csr.1303

Simnett, R., Vanstraelen, A., \& Chua, W. F. (2009). Assurance on sustainability reports: An international comparison. The Accounting Review, 84(3), 937-967. doi:10.2308/accr.2009.84.3.937

Sweeney, L., \& Coughlan, J. (2008). Do different industries report corporate social responsibility differently? An investigation through the lens of stakeholder theory. Journal of Marketing Communications, 14(2), 113-124. doi:10.1080/13527260701856657

Tschopp, D. J. (2005). Corporate social responsibility: A comparison between the United States and the European Union. Corporate Social Responsibility and Environmental Management, 12(1), 55-59. doi:10.1002/csr.69

Ullmann, A. A. (1985). Data in search of a theory: A critical examination of the relationships among social performance, social disclosure, and economic performance of US firms. Academy of Management Review, 10(3), 540-557. doi:10.5465/amr.1985.4278989

Vafeas, N. (1999). Board meeting frequency and firm performance. Journal of Financial Economics, 53(3), 113-142. doi:10.1016/s0304405x(99)00018-5

Willekens, M., Bauwhede, H. V., Gaeremynck, A., \& Gucht, L. Van de. (2005). Internal and external governance and the voluntary disclosure of financial and non-financial performance. XV National BAA Auditing SIG Conference, Aston, United Kingdom.

Williamson, O. E. (2000). The new institutional economics: Taking stock, looking ahead. Journal of Economic Literature, 38(3), 595-613.

Yermack, D. (1996). Higher market valuation of companies with a small board of directors. Journal of Financial Economics, 40(2), 185-211. doi:10.1016/0304-405X(95)00844-5

Young, S., \& Marais, M. (2012). A multi-level perspective of CSR reporting: The implications of national institutions and industry risk characteristics. Corporate Governance: An International Review, 20(5), 432-450. doi:10.1111/j.1467-8683.2012.00926.x 